\title{
PSIHOLOŠKO-DIDAKTIČNI VIDIKI TUTORSKE PODPORE V E-IZOBRAŽEVANJU
}

Izr. prof. $d r$. Marko Radovan Filozofska fakulteta Univerze $v$ Ljubljani

\section{POVZETEK}

V prispevku bomo zajeli glavne vidike tutorske podpore v e-izobraževanju, ki jih mora tutor upoštevati pri načrtovanju svojega dela. Z vidika teorij konstruktivizma in konektivizma bomo prikazali vlogo tutorja pri spodbujanju in usmerjanju učenja v e-izobraževalnem programu. Konektivizem je novejša teorija učenja, ki znanje umešča v sisteme, ki so ljudem dostopni prek sodelovanja v dejavnostih; ima prav posebno vlogo na področju e-izobraževanja, saj poudarja pomen in učinek tehnologije na način, kako živimo, kako se sporazumevamo in kako se učimo. Ugotovili bomo tudi, da konektivizem poudarja predvsem uporabo metod izkustvenega učenja, aktivnost udeleženca pri učenju ter pomen refleksije. V članku bodo še predstavljene glavne tutorjeve kompetence in vidiki načrtovanja njegovega dela.

Ključne besede: tutorska podpora, tutorjeve kompetence, e-izobraževanje, konektivizem, teorije o učenju.

\section{PSYCHOLOGICAL AND DIDACTICAL ASPECTS OF ANDRAGOGICAL SUPPORT IN E-LEARNING - ABSTRACT}

The article deals with the main principles of andragogical support a tutor needs to consider when planning his work in e-learning of adults. The tutor's role in encouraging and guiding learning in an e-learning programme is presented from the point of view of constructivist and connectivist theories. Connectivism is a relatively new theory of learning, which sees knowledge as existing within systems which are accessed through people participating in activities. It has a special importance in the field of e-learning, since it emphasizes the role and effect technology has on how people live, how they communicate, and how they learn. The article shows that connectivism advocates the use of experiential learning methods, the learner's active participation in the learning process, and emphasizes the role of reflection. In addition, it presents the main competences of a tutor and the planning aspects of his work.

Keywords: tutor's support, e-learning, connectivism, theories of learning.

UDK: $374.7: 371.68$

\section{UVOD}

Udeleženci e-izobraževanja potrebujejo za doseganje učnih ciljev podporo pri učenju (učna gradiva in učne pripomočke ter tutorsko podporo) in drugo podporo (administrativne, tehnične, svetovalne, organizacijske storitve). Konceptualno je model tutorske podpore v e-izobraževanju enak kot $\mathrm{v}$ tradicionalnih modelih izobraževanja na daljavo, razlike so $\mathrm{v}$ načinu izvedbe. Sodobna tehnologija namreč daje za izpeljavo podpore $\mathrm{v}$ e-izobraževanju veliko novih možnosti z vidika uporabe medijev in tehnologije pri pripravi učnih pripomoč- kov in gradiv, pa tudi z vidika komunikacije pri tutorski podpori. Ko se odločamo za izbiro oblik učne podpore za neki program e-izobraževanja, moramo upoštevati značilnosti udeleženca, učno snov in značilnosti učečih se.

\section{TEORIJE O UČENIU}

Tutorska podpora je v marsičem odvisna od teorije učenja, na kateri temeljijo njena izhodišča. Pogled na to, kako se ljudje učijo, ali na razumevanje učnega procesa naj bi bilo iz- 
hodišče za to, kako poučujemo, in tudi, kako uporabljamo tehnologijo za poučevanje. Teorije o učenju, ki se najpogosteje omenjajo v povezavi z e-izobraževanjem, so vedenjska, kognitivna, konstruktivistična in konektivistična. Vedenjska teorija temelji na domnevi, da bo

\section{$V$ zadnjem stoletju je razumevanje procesa učenja pre- cej napredovalo.} določena stimulacija izzvala določen odgovor (primer: ko se poveča svetloba, se zenica zmanjša), in zavrača miselne aktivnosti kot podlago za učenje. Učenje je determinirano $\mathrm{z}$ zunanjimi dejavniki, ki pripomorejo k okrepitvi udeleženčevega vedenja na pričakovani način (Bates, 1997: 44). Z nagrado ali kaznijo je mogoče zvezo med določenim stimulusom in določenim odgovorom ali odzivom okrepiti. Ta teorija temelji na domnevi, da je človeško vedenje predvidljivo in da ga je mogoče nadzorovati. Odsev vedenjske teorije lahko vidimo $\mathrm{v}$ razvoju učnih strojev (Jolliffe, Ritter in Stevens, 2001), merljivih učnih ciljih, programiranem pouku in računalniško podprtem poučevanju (angl. computer-assisted instruction). Še do nedavnega je veljalo, da so računalniki tesno povezani $\mathrm{z}$ vedenjskim načinom učenja. Po drugi strani pa privrženci kognitivne teorije menijo, da so za učenje bistveni mentalni procesi - notranje in zavedne predstave sveta. Posameznik ni le nekakšen mehaničen proizvod okolja, temveč dejavni udeleženec učnega procesa, ki namenoma poskuša predelati informacije, pridobljene iz zunanjega sveta. Temeljne značilnosti kognitivizma so torej iskanje pravil, načel ali odnosov pri procesiranju novih informacij in iskanje smisla pri usklajevanju novih informacij s prejšnjim znanjem (Bates in Poole, 2003: 33).

V konstruktivistični teoriji je najpomembneje, da se učenje pojmuje predvsem kot družbeni proces, ki zahteva komunikacijo ne le med udeležencem in učiteljem, temveč tudi med udeleženci, kolegi, prijatelji ipd. Tega družbenega procesa se ne da nadomestiti s tehnologi- jo, lahko pa ga ta olajša. Znanje se pridobiva $\mathrm{v}$ družbenem procesu ali v organizacijah, ki jih je ustvarila družba. S konstruktivističnega vidika je tudi znanje, ki je označeno kot »veljavno«, proizvod družbene konstrukcije. Znanje namreč ni le vsebina, temveč tudi izraz vrednot, zato ga je treba nenehno raziskovati in biti do podanega znanja kritičen (Bates in Poole, 2003: 34). V tem smislu si tudi posameznik zavestno prizadeva, da bi svoje okolje razumel glede na pretekle izkušnje in svoje trenutno stanje. Čeprav so si omenjene teorije o učenju v marsičem kontradiktorne, to še ne pomeni, da jih ne moremo koristno uporabiti pri poučevanju. Za pridobivanje nekaterih vrst znanja so na primer primernejše vedenjske teorije kot konstruktivistične, čeprav obstaja danes močna težnja odmika od vedenjskih teorij. Različni pristopi $\mathrm{k}$ poučevanju naj se uporabljajo glede na učne potrebe $\mathrm{v}$ različnih kontekstih. Zato je treba identificirati primerne načine učenja za posamezne učne naloge in skupine udeležencev ter se nato odločiti, kako naj bi uporabili tehnologijo, da bi zadostila tem potrebam. Za učenje, ki temelji na konstruktivističnih teorijah, je značilno, da je učitelj neke vrste pomočnik, ki pomaga udeležencu učiti se, med njima pa poteka komunikacija. Pri konstruktivističnem pristopu je ena od najpomembnejših oblik učne podpore skupinska razprava.

V zadnjem stoletju je razumevanje procesa učenja precej napredovalo. Za začetek 20. stoletja je bila značilna vedenjska teorija, ki je ustrezala industrijski dobi. Sredi 20. stoletja sta se zaradi pomanjkljivosti vedenjske teorije razvili dve novi teoriji o učenju - kognitivna in konstruktivistična. V zadnjem desetletju je znanost o učenju spet znatno napredovala. Opravljenih je bilo veliko raziskav, katerih izsledki se lahko uporabijo kot vodilo pri odločanju o pripravi učnih aktivnosti in pristopov za učinkovito vključevanje udeležencev (Siemens in Tittenberger, 2009: 9). Vse tri prevladujoče teorije o učenju, tj. vedenjska, kognitivna in konstrukti- 
vistična, izhajajo iz mišljenja, da je znanje neki cilj ali stanje, ki se ga da doseči z mišljenjem in izkušnjami in z upoštevanjem tega, kako si posameznik pridobi znanje ali kako se uči. Ukvarjajo se z učnim procesom, ne pa $\mathrm{z}$ vrednostjo naučenega. $Z$ naraščanjem obsega znanja in informacij v sodobni družbi pa je postala pomembna hitra evalvacija znanja, saj moramo delovati (in to hitro) na podlagi informacij, ki so zunaj našega primarnega znanja.

V zadnjem času se tako uveljavlja nova teorija o učenju, tj. konektivizem ali konektivistična teorija (Siemens, 2004; 2007; Siemens in Tittenberger, 2009). Konektivizem temelji na domnevi, da je znanje porazdeljeno po človeških, družbenih in tehnoloških omrežjih in da je učenje proces povezovanja, širjenja in upravljanja teh omrežij.

Teorija konektivizma temelji na teoriji kaosa in na pomenu omrežij oziroma medsebojnega povezovanja v sodobni družbi. Teorija kaosa predpostavlja povezavo vseh z vsemi.

Temeljna načela konektivizma so (Siemens, 2004):

- učenje in znanje se manifestirata $\mathrm{z}$ različnostjo pogledov in mnenj;

- učenje je proces povezovanja specializiranih informacijskih virov;

- znanje lahko obstaja zunaj človeka;

- odločilna je sposobnost vedeti več;

- za posodabljanje znanja je odločilno vzdrževanje povezav;

- temeljna sposobnost je sposobnost prepoznavanja povezav med področji, zamislimi in koncepti;

- temeljni cilj učenja je pridobivati najaktualnejše znanje.

Po konektivistični teoriji je učenje proces, ki poteka v spremenljivih okoljih, na katere posamezniki praviloma ne morejo vplivati. Znanje obstaja $\mathrm{v}$ različnih omrežjih (računalniških, družbenih), v sodobni družbi pa je najpomembneje znati povezovati različne vire informacij. To povezovanje nam omogoči, da se več naučimo, in je pomembnejše od našega trenutnega stanja znanja (Siemens, 2007). Vloga učitelja v konektivizmu je, da vodi, usmerja in izboljšuje kakovost omrežij, ki jih oblikujejo učeči se (Siemens in Tittenberg, 2009: 13). Kljub dobremu poznavanju računalnikov učečim se še vedno primanjkuje kritičnosti ter strokovnega znanja za vrednotenje in interpretiranje informacij, ki jih najdejo »on-line « (JISC, 2009: 7).

\section{SPLOŠNE ZNAČILNOSTI UČNE PODPORE V E-IZOBRAŽEVANJU}

Ena temeljnih značilnosti e-izobraževanja so sistemi podpore, katerih poglavitni namen je omiliti težave, ki jih prinaša prostorska ločenost udeleženca izobraževanja in učitelja $\mathrm{v}$ procesu takega izobraževanja. Sistemi učne podpore udeležencev zajemajo učne pripomočke in gradiva, oblikovana tako, da omogočajo uresničevanje učnih ciljev v pogojih prostorske ločenosti udeležencev in učiteljev. Udeleženci pa potrebujejo za doseganje teh ciljev tudi pomoč v obliki različnih storitev; to organizirajo izobraževalne organizacije in jo dajejo tutorji, svetovalci, administrativno in tehnično osebje. Na splošno dajejo tutorji udeležencem pomoč, ki je povezana $\mathrm{z}$ učenjem in ki skupaj z učnimi gradivi pomeni učno podporo, svetovalci, administrativno in tehnično osebje pa se ukvarjajo z osebnim in drugimi vrstami svetovanja, ki ni neposredno povezano s procesom učenja $\mathrm{v}$ programu (nepedagoška podpora). Tutorska podpora se v praksi pogosto prepleta $\mathrm{z}$ oblikami nepedagoške podpore, odvisno predvsem od organizacijskega modela in kadrovskih zmogljivosti organizacije.

Konceptualno je model tutorske podpore $\mathrm{v}$ e-izobraževanju enak kot $\mathrm{v}$ tradicionalnih modelih izobraževanja na daljavo, razlike so v načinu izvedbe. V tradicionalnem izobraževanju na daljavo poteka tutorska podpora $\mathrm{v}$ obliki skupinskih tutorskih srečanj $\mathrm{v}$ živo ali pa neposrednih individualnih stikov udeleženca in tutorja v živo, s stiki po telefonu, pisnimi spo- 
ročili ter uporabo (predvsem tiskanih) učnih gradiv, pripravljenih skladno s posebnostmi izobraževanja na daljavo. Sodobna tehnologija daje veliko novih možnosti za izpeljavo tutorske podpore $\mathrm{v}$ e-izobraževanju tako $\mathrm{z}$ vidika uporabe medijev in tehnologije kot tudi $\mathrm{z}$ vidika značilnosti komunikacije. Ena bistvenih značilnosti e-izobraževanja je, da temelji ta podpora večinoma na uporabi sodobne IKT. Pri odločanju, katere medije in tehnologije ter katere oblike podpore bomo uporabili pri nekem programu e-izobraževanja, moramo upoštevati značilnosti udeleženca, učno snov, vsebino in značilnosti učnega okolja ter seveda vire, ki so na voljo. Posebno pomembno je, da predvidimo, kakšna so pričakovanja o tutorski pa tudi netutorski podpori, ki jih ima udeleženec ob začetku e-izobraževanja. Udeleženec pričakuje predvsem:

- točne in veljavne informacije,

- prožno učenje, prilagojeno različnim učnim pristopom,

- svetovanje o tem, kaj in kako naj se uči (o vsebini in načinu učenja),

- možnost uporabe že naučenega in svojih izkušenj pri učnem procesu,

- povratne informacije o uspešnosti učenja,

- pomoč $\mathrm{v}$ zvezi $\mathrm{z}$ administrativnimi in drugimi težavami, ki so povezane s programom.

Pri načinu komuniciranja je poglavitni razlikovalni dejavnik med komunikacijskimi orodji ta, ali je komunikacija asinhrona ali sinhrona. Pri tradicionalnem izobraževanju poteka komunikacija sočasno, sinhrono. Pri tradicionalnem izobraževanju na daljavo se določena stopnja asinhronosti komuniciranja dosega predvsem s pisno komunikacijo, pri e-izobraževanju pa elektronsko okolje dopušča, da komunikacija poteka bodisi v realnem času ali pa neodvisno od časa in/ali prostora.

\section{Temeljne vrste podpore v e-izobraževanju}

Podporo v programih e-izobraževanja sestavljajo učna gradiva in pripomočki ter tutor- ska podpora. Glede na razpoložljivost učnih gradiv za programe e-izobraževanja razlikujemo vire informacij, ki so na voljo na spletu (spletni viri) in posebej za program e-izobraževanja oblikovana spletna gradiva (avtorska spletna gradiva). Med spletne vire uvrščamo spletne portale, podatkovne zbirke, spletne revije, knjižnice računalniških programov in spletne strani različnih interesnih skupin. Med avtorska spletna gradiva navadno prištevamo osnovna gradiva, pripravljalna gradiva, elektronske oglasne deske, pogosta vprašanja z odgovori in zglede vprašanj za preverjanje znanja. Razvoj IKT s pojavom spleta 2.0 omogoča nove informacijske storitve, uporabne tudi za e-izobraževanje, kot so prostodostopni viri, socialno zaznamovanje, podkasti, souporaba slik. Podlaga tutorski in tudi različnim oblikam nepedagoške podpore je komunikacija, ki lahko poteka kot sinhrona ali pa kot asinhrona. Najbolj razširjene in uporabne vrste asinhrone komunikacije so elektronska pošta, seznami prejemnikov in diskusijski forumi, s pojavom spleta 2.0 pa se vse bolj uveljavljajo blogi, mikroblogi, wikiji in različne oblike socialnega mreženja. Sinhrona komunikacija poteka s pomočjo klepetalnic, avdio-, video- in spletnih konferenc. V e-izobraževanju se vse bolj uporablja komuniciranje z uporabo mobilnih tehnologij (mobilno učenje), ki je lahko sočasno ali pa z zamikom.

\section{VLOGA TUTORJA V E-IZOBRAŽEVANJU}

Tutor potrebuje za uspešno izpeljavo e-izobraževanja poleg tradicionalnega znanja o poučevanju še dodatna kompetence, ki so specifične za e-izobraževanje. Predvsem so pomembne komunikacijske in motivacijske sposobnosti ter obvladovanje IKT. Aktivnosti tutorjev sistematično prikažemo $\mathrm{z}$ modelom e-tutorstva, ki zajema pet stopenj: dostop do e-okolja, spoznavanje v e-izobraževanju, izmenjava informacij, ustvarjanje znanja in ra- 
zvoj. Vsaka posamezna stopnja predvideva specifično tutorjevo znanje in kompetence ter določen obseg interakcije z udeleženci. Vse to moramo upoštevati pri usposabljanju tutorjev pa tudi pri načrtovanju tutorjevih aktivnosti za posamezen program e-izobraževanja. Pri načrtovanju tutorjevega dela moramo upoštevati tudi konkretne okoliščine, $\mathrm{v}$ katerih poteka program, na primer značilnosti organizacije, velikost skupine, obvladovanje komunikacije in časovno načrtovanje.

\section{Spremenjena vloga učiteljev in udeležencev izobraževanja}

E-izobraževanje postaja vse bolj priljubljena in razširjena oblika izobraževanja. Na trgu je veliko orodij, ki nam omogočajo tehnično preprosto in hitro oblikovanje programov e-izobraževanja, vendar samo tehnične možnosti ne zadoščajo za uspešno izpeljavo programa. Potrebna je ustrezna podpora. Poleg ustreznih gradiv, prilagojenih posebnostim in možnostim e-izobraževanja, so pomemben dejavnik kakovostne podpore $\mathrm{v}$ e-izobraževanju tudi usposobljeni in kakovostni tutorji, ki so zmožni to izobraževanje učinkovito organizirati in strokovno korektno izpeljati.

V e-izobraževanju so tutorji nekakšen vmesnik med organizacijo, ki organizira izobraževanje, in udeleženci. Zato mora tutor dobro poznati orodja pa tudi tehnike in načine poučevanja, ki so primerni za e-izobraževanje. Koristno je, da ima izkušnje s poučevanjem in tradicionalna pedagoška ali andragoška znanja. Zato so tutorji pogosto iz vrst učiteljev v tradicionalnem izobraževanju, specifična znanja in kompetence pa si pridobijo $\mathrm{z}$ dodatnim usposabljanjem. Značilnosti tutorja bomo podrobneje predstavili v nadaljevanju.

Tutor sodeluje v več aktivnostih, kot so podpora udeležencem, vodenje razprav, sodelovanje in moderiranje, ki potekajo predvsem kot elektronska pisna komunikacija (z diskusijami v forumih, po elektronski pošti, v blogih, kle- petalnicah idr.). Te interakcije lahko potekajo sočasno, »v živo (sinhrona komunikacija), ali pa niso vezane na čas (asinhrona komunikacija). E-izobraževanje omogoča tudi uporabo različnih sredstev poučevanja in vključevanje večpredstavnostnih medijev, avdio- in videoposnetkov, grafike, možnost za izmenjavo gradiv in mnenj $v$ skupnem virtualnem okolju. Vse to vpliva tako na značilnosti poučevanja kot tudi na vlogo tutorja in udeleženca $\mathrm{v}$ tem procesu. Tako učitelj kot tudi tutor strokovno usmerjata in vodita udeležence $\mathrm{v}$ celotnem učnem procesu, jih motivirata, sodelujeta $\mathrm{z}$ njimi, jih ocenjujeta in se ukvarjata z marsikaterimi težavami, ki nastajajo med izvajanjem programa. Tutorjeva vloga se loči od učiteljeve predvsem po obsegu in načinu komuniciranja. $\mathrm{V}$ e-izobraževanju je med tutorjem in udeležencem navadno več medsebojnega komuniciranja kot $\mathrm{v}$ tradicionalnem izobraževanju, kjer je poudarek na skupinski komunikaciji. Pogosto je vloga učitelja ali predavatelja omejena le na podajanje znanja in navodil $\mathrm{v}$ zvezi $\mathrm{z}$ učenjem za neki predmet celotni skupini, stiki z udeleženci pa so največkrat omejeni le na čas predavanj. Četudi se tradicionalno izobraževanje vse bolj »informatizira « in so zaposleni v izobraževalnih organizacijah z udeleženci bolj povezani (na primer po elektronski pošti, ponekod pa tudi na šolskem spletnem portalu), kakor so bili včasih, pa se porazdelitev vlog v izobraževalnem procesu ni veliko spremenila. Učitelj v razredu natančno predstavi, kaj se je treba naučiti, in to snov predava ali razlaga. $\mathrm{V}$ e-učnem okolju pa je tutor praviloma le eden od udeležencev in ves čas v interakciji z udeleženci. Če želi, da bodo forumi in klepetalnice zaživeli, mora razprave spodbujati, usmerjati in vrednotiti. Med njegove naloge torej poleg vsebinskih prispevkov $\mathrm{k}$ razpravi sodita tudi organiziranje in moderiranje učenja. Tutorji, ki prihajajo v (živi ali virtualni) stik z udeleženci, pomenijo za izobraževalno organizacijo kadrovsko jedro e-izobraževanja. Vsi drugi sodelujoči strokovnjaki (na primer admini- 
stratorji, pisci učnih gradiv itn.), ki sodelujejo pri razvoju in izpeljavi e-izobraževanja, imajo praviloma manj stika z udeleženci.

Tako učitelj kot
tutor strokovno
usmerjata in vo-
dita udeležence $v$
celotnem učnem
procesu.

Sprememba vloge tutorja glede na vlogo učitelja vpliva tudi na vlogo udeležencev e-izobraževanja. Večja enakopravnost in aktivnost pri pridobivanju znanja zahteva od udeležencev veliko več časa in truda, zaradi ciljev, ki narekujejo tempo učenja, pa tudi več samodiscipline in motivacije.

\section{Tutorjeve kompetence v e-izobraževanju}

Tutor mora pri svojem delu upoštevati posebnosti e-učenja. Z vidika njegovega dela je bistveno naslednje:

- E-učenje omogoča izmenjavo različnih izkušenj, ki izhajajo iz vsakdanjega poklicnega in zasebnega življenja udeležencev. Ta oblika znanja je pogosto neformalna, skrita in se nenehno razvija. Udeleženci si širijo znanje $\mathrm{z}$ dinamičnimi procesi izmenjave informacij in izkušenj. Pri tutorstvu je zelo redko poučevanje $\mathrm{v}$ tradicionalnem pomenu. Udeleženci so navadno precej samostojni in manj odvisni od tutorja. V e-izobraževanju lahko udeleženci sami najdejo informacije, namesto da bi morali samo sprejeti tisto, kar jim določa tutor. Znanje torej pridobivajo $\mathrm{v}$ interakciji z drugimi udeleženci. Tutor mora takšno komunikacijo spodbujati, četudi se s tem njegova vloga zmanjšuje.

- Udeleženci niso fizično navzoči. To pomeni, da si tutor pri spremljanju učnega procesa ne more pomagati z neverbalno komunikacijo, morda pa s tonom glasu in slogom pisanja.

- Tutor mora za komuniciranje uporabljati različne medije: zapisana besedila, govor, slike, predstavitve, video, za to pa potrebuje nekatere spretnosti, ki niso samo tehnične narave (Bregar, Zagmajster in Radovan, 2010: 262-263).

\section{Načrtovanje tutorjevega dela}

Pri načrtovanju svojega dela mora tutor upoštevati več dejavnikov: posebnosti procesa e-učenja, ki poteka v več stopnjah, organiziranje dela in velikost skupine, veščine asinhrone komunikacije, časovno načrtovanje in mreženje (povezovanje).

\section{Organiziranje dela in velikost skupine}

Kakšna je ustrezna velikost skupine $\mathrm{v}$ e-izobraževanju, da bomo dosegli čim večjo učinkovitost in uspešnost učenja? Optimalno število udeležencev je odvisno predvsem od namena in ciljev programa e-izobraževanja. Majhne skupine lahko neposredno sodelujejo med seboj in s tutorjem ter se dejavno ukvarjajo s postavljenimi nalogami ali problemi. Vzdušje je bolj osebno, včasih celo bolj kot v tradicionalnem izobraževanju.

Za uspešen začetek skupinskega dela je zaželen ustrezen uvodni pozdrav z dobrimi željami in pričakovanji glede skupnega dela $\mathrm{v}$ programu. Naslednji tutorjev korak je, da udeležencem pojasni, kako pogosto bo pregledoval njihove izdelke in se odzival na vprašanja. Precej pogosta praksa je enkrat na dan ali najmanj trikrat na teden. Če iz kakršnihkoli razlogov tutor te obveznosti ne more opraviti, mora udeležence o tem obvestiti in jim tudi sporočiti, na koga se lahko obrnejo. Tutor mora udeležence tudi vnaprej opozoriti, kako pogosto naj pregledujejo obvestila, objavljena na spletu.

Tutor mora tudi spodbujati sodelovanje udeležencev, ki mora biti usklajeno z učnimi cilji. Četudi je tutorjevo delo v e-izobraževanju navzven manj opazno, pa mora $v$ skupini delovati proaktivno, ne pa poteka učenja pasivno prepuščati spontanemu toku. Aktivno uravnavanje dela skupine dosega tutor z naslednjimi aktivnostmi (Horton, 2006: 473):

- individualni stiki z udeleženci: koristno je, da z udeleženci navezuje stike posamično (z elektronsko pošto ali po telefonu) in jim tako da vedeti, da jih obravnava kot indi- 
viduume ter da jim je resnično na voljo in pripravljen pomagati pri reševanju njihovih učnih težav;

- pomoč pri navezovanju stikov med vrstniki (udeleženci) v skupini: udeležence spodbuja, da se predstavijo (na primer z blogom), in tako omogoči, da se medsebojno bolje spoznajo in poiščejo skupne interese;

- dosledno spoštovanje objavljenega programa aktivnosti: upoštevati mora, da so udeleženci že prilagodili svoje obveznosti napovedanim aktivnostim $\mathrm{v}$ programu in da bi jim vsak odmik od programa povzročil precej težav in sitnosti.

Tutor mora stalno spremljati sodelovanje udeležencev $\mathrm{v}$ razpravah in drugih aktivnostih in se, če je treba, pravočasno odzvati, da (če je le mogoče) prepreči prekinitev učenja.

Ena najpomembnejših in najzahtevnejših na$\log$ tutorja je moderiranje diskusijskih forumov. Kolikor bolj zavzeto bo spodbujal sodelovanje in ustvarjalnost udeležencev, blažil napetosti in nesporazume ter nasploh znal razgibati razpravo, tem bolj bodo udeleženci dejavni. Seveda pa ob potrebni strokovnosti in izkušenosti za tako zavzeto delo tutor porabi tudi veliko časa. $S$ tega vidika je velikost skupine, ki jo usklajuje, zelo pomembna. Upoštevati moramo, da zahteva komunikacija v e-izobraževanju nasploh precej več časa kot tradicionalna komunikacija v živo. Horton (2006) meni, da velja upoštevati pravilo, po katerem potrebujemo v primerjavi z 10-minutnim stikom v živo za:

- avdiokonferenco 20 minut,

- klepetalnico 30 minut,

- diskusijski forum od enega do dva dni.

Prav tako opozarja, da za razpravo, primerljivo $\mathrm{z}$ enourno diskusijo $\mathrm{v}$ živo $\mathrm{v}$ razredu, na diskusijskem forumu potrebujemo približno teden do 10 dni. Zaradi navedenih razlogov zahteva vodenje skupin v e-izobraževanju manjše število udeležencev $\mathrm{v}$ primerjavi $\mathrm{z}$ vodenjem diskusij v tradicionalnem šolskem okolju, kjer je okoli 20 udeležencev. Najbolj priporočljivo je, da je v skupini od sedem do 10 udeležencev (prav tam). Seveda pa je pri odločanju o velikosti skupine treba upoštevati tudi ekonomski vidik, saj so stroški na udeleženca v majhni skupini precej višji.

Če si iz ekonomskih razlogov ne moremo privoščiti izpeljave programa $\mathrm{v}$ majhnih skupinah, potem poskušamo čim bolj kakovostno e-izobraževanje zagotoviti tako, da za izpeljavo le nekaterih aktivnosti skupino razbijemo $\mathrm{v}$ majhne učne skupine do 10 udeležencev.

\section{Veščine asinhrone komunikacije}

Včasih se izkaže, da je uporaba asinhrone komunikacije za tutorje začetnike zahtevno opravilo, posebno takrat, kadar imajo opraviti z več udeleženci. Udeleženci lahko prebirajo sporočila in nanje odgovarjajo na več forumih ali temah hkrati, sočasno lahko odprejo celo novo temo, postavljajo vprašanja, ki zadevajo udeležence ali pa samo tutorja. Uporabljajo lahko tudi druga orodja asinhrone komunikacije, na primer elektronsko pošto, bloge, wikije in podobno.

Takšna razvejanost in raznolikost možnih oblik interakcije lahko tutorju povzroča precej težav. Težka sledljivost in majhen nadzor nad aktivnostmi udeležencev $\mathrm{v}$ asinhronih diskusijah lahko slabita motiviranost in osredotočenost udeležencev na učne cilje. Zato je pomembno, da tutorji sebi in udeležencem olajšajo delo tako, da naloge, metode dela in cilje opredelijo vnaprej, z navedbo časovnih rokov za izpeljavo nalog in za pošiljanje povratnih informacij. Priporočljivo je, da za tutorje pripravimo poseben priročnik, $\mathrm{v}$ katerem najdejo konkretne napotke, kako izpeljati program z organizacijskega (priprava osnovnih informacij in registracija udeležencev, obveščanje, dostop do virov, roki itn.) in pedagoškega vidika (načrtovanje in izvedba diskusijskih forumov, sinhrone komunikacije in druge aktivnosti).

Za tutorja je posebno pomembno uspešno organiziranje in moderiranje diskusijskih forumov kot ene izmed najučinkovitejših in naj- 
primernejših oblik e-izobraževanja. Ustrezna organizacija diskusijskih forumov pomeni, da udeležence ob prvem obisku diskusijskega fo-

Sodobna tehnologija hkrati z družbenimi in političnimi spremembami nesporno spreminja izobraževanje in s tem učenje. ruma pričakajo vse informacije, ki jih potrebujejo za nemoteno in dejavno sodelovanje.

Takšne informacije so:

- predstavitev teme diskusijskega foruma in učnih ciljev;

- informacije o administrativnih in tehničnih vidikih foruma in o ustrezni podpori;

- vsebinske informacije splošne narave, ki jih ni mogoče uvrstiti $\mathrm{v}$ posamezno temo (na primer uporabne povezave, pojmovniki in podobno);

- informacije o možnostih za izmenjavo mnenj med udeleženci zunaj diskusijskega foruma;

- napotki, kako izvajati posamezne funkcije na diskusijskem forumu (na primer, kakšne so možnosti za odgovarjanje na sporočila, za nove objave in za odpiranje novih tem, za urejanje in zagotavljanje preglednosti objav). $\mathrm{Z}$ moderiranjem diskusijskih forumov mora tutor predvsem poskrbeti, da bo razprava med udeleženci konstruktivna ter bo pripomogla k poglabljanju že pridobljenega znanja udeležencev in $\mathrm{k}$ pridobivanju novega. To dosega $\mathrm{z}$ domiselnim odpiranjem novih tem in postavljanjem zanimivih vprašanj, $\mathrm{z}$ ustreznim odzivanjem na vsa vprašanja, na katera se udeleženci dalj časa ne odzovejo, z opozarjanjem na napake ali nepravilno razumevanje, izločanjem nepotrebnih ali neprimernih sporočil, vključevanjem zanimivih »gostov « v forum ter navsezadnje $\mathrm{z}$ evalvacijo in povzemanjem razprave.

\section{PRIHODNOST E-IZOBRAŽEVANIA IN TUTORJEVEGA DELA}

Sodobna tehnologija hkrati z družbenimi in političnimi spremembami ter vse višjo stopnjo globaliziranosti sveta nesporno spreminja izobraževanje in s tem učenje. Te spremembe se uveljavljajo razmeroma počasi, z neenakomerno dinamiko in različno stopnjo vključenosti različnih družbenih segmentov. Ne glede na vse te razlike pa je izobraževanje danes zagotovo precej drugačno kot pred dvema, tremi desetletji. Za izobraževanje danes so značilne naslednje razvojne težnje (Ehlers, 2009: 135):

- izobraževanje poteka vsepovsod in na različnih mestih, v različnih oblikah, različnih okoliščinah, še zdaleč ne samo v razredu;

- učeči se vse bolj prevzemajo vlogo organizatorja izobraževanja;

- učenje je vseživljenjski proces, ki poteka v različnih obdobjih in se ne povezuje zgolj z izobraževalnimi ustanovami;

- učenje poteka $\mathrm{v}$ učnih skupnostih, ki so lahko formalne ali priložnostne narave;

- učenje ni več osredotočeno na učitelja ali ustanovo.

Pomemben spodbujevalec teh sprememb, zlasti z vidika uporabe IKT, so mlajše generacije, digitalne generacije (angl. digital natives; $n$ -gens), rojene v 80. letih prejšnjega stoletja in pozneje (Prensky, 2007). Predstavniki te generacije se dela, učenja ali pridobivanja znanja in drugih aktivnosti lotevajo drugače kot prejšnje generacije. Zanje je značilno, da so navajeni informacije sprejemati sočasno iz več virov, hitro, a površinsko. Informacije iščejo po potrebi, in ne na zalogo, nenehno komunicirajo in raje ustvarjajo svoje medije, kot pa da bi kupili knjigo ali zgoščenko. Komuniciranje z uporabo tehnologije, večinoma na daljavo, je nepogrešljiv del njihovega življenja in poglavitni način navezovanja socialnih stikov. Te spremembe se v izobraževanju kažejo kot usmeritev k učečemu se (angl. learner-centered). Spodbujajo jih tudi demografska gibanja, ki poudarjajo pomen mladih, in kulturno-socialna gibanja, ki postavljajo $\mathrm{v}$ ospredje uporabnika kupca ter prilagajanje njegovim zahtevam oziroma potrebam. Ta gibanja nakazujejo razvoj novega, že omenjenega konektivističnega izobraževalnega modela, ki izhaja iz stališča, da je znanje ali razumevanje prisotno v 
omrežjih med ljudmi in da je učenje proces povezovanja, rasti in navigiranja po teh omrežjih (Siemens in Tittenberger, 2009: 11).

Oblikovanje novega izobraževalnega modela podpira tudi razvoj interneta, ki gre vse bolj v smeri socialnih omrežij. Novo stopnjo v razvoju spleta so raziskovalci poimenovali splet 2.0 (angl. web 2.0), kar je skupno ime za nove, inovativne pristope pri uporabi spleta. Novi načini uporabe interneta ali nove spletne storitve 2.0 seveda ne bi bili mogoči brez inovativnih tehnologij, kot je mobilna tehnologija, prilagodljivo učno okolje (angl. adaptive learning environment - ALE), prostodostopni sistemi, ter brez razvoja ustreznih orodij in standardizacije. Glavna orodja spleta 2.0 so (Siemens in Tittenberger, 2009: 14):

- spletno objavljanje (blogi, wikiji, e-portfelji),

- govor v omrežju IP (npr. Skype),

- mobilno učenje (npr. mobilniki, tablični računalniki),

- virtualni interaktivni svetovi (npr. Second Life, Voice Thread),

- integrirane učilnice (npr. Elluminate),

- diskusijski forumi s pomočjo LMS ali zunanjih aplikacij,

- klepetalnice (IRC, IM),

- grafično podprte povezave (npr. Flickr),

- programska podpora za skupine (Sharepoint Grove),

- orodja za socialno povezovanje (angl. social networking, npr. Facebook, Twitter, ELGG, MySpace),

- orodja za socialno zaznamovanje (angl. social bookmarking, npr. Delicious.com).

Kaj pomeni razvoj spleta 2.0 za tutorjevo delo? Za splet 2.0 je značilno, da so informacije razgrajene $\mathrm{v}$ mikrovsebinske enote, $\mathrm{ki}$ jih je mogoče posredovati na desetine različnih vsebinskih področij. Tradicionalni spletni informacijski viri se vse manj uporabljajo, v ospredje prihajajo nova orodja, ki omogočajo povezovanje (agregiranje) in ustvarjalno uporabo mikrovsebin na nove načine in $\mathrm{z}$ novimi funkcijami. Transformacija svetovnega sple- ta vodi tudi k transformaciji e-izobraževanja. Teorija in praksa e-izobraževanja sta že umestili pojem e-izobraževanje 2.0. Kljub nekaterim različnim pogledom se za e-izobraževanje 2.0 navajajo naslednje skupne značilnosti (Downes, 2005):

- udeleženci oblikujejo vsebino sami in sodelujejo s kolegi v blogih, wikijih, tematskih diskusijah, samodejnem obveščanju (angl. RSS - really simple syndication) in drugih oblikah omrežij, ki omogočajo decentralizirano nastajanje vsebin in porazdelitev odgovornosti;

- e-izobraževanje izrablja prednosti, ki jih daje bogastvo spletnih virov, in jih povezuje v nove učne izkušnje;

- e-izobraževanje temelji na kombinirani uporabi raznovrstnih orodij, ki sicer niso povezana in so dostopna na različnih mestih (na primer spletne reference, učna gradiva in članki, orodja za upravljanje znanja, sodelovanje, iskanje).

E-izobraževanje torej postaja vse bolj podlaga za izmenjavo znanj in vse manj medij za prenašanje informacij. Vsebina se ustvarja in uporablja, njeni ustvarjalci so prostorsko neodvisni udeleženci »izobraževanja«. Pasivno sprejemanje informacij, ki so jih pripravili drugi, se pomika $\mathrm{v}$ ozadje, tutorjevo delo pa zadeva več interakcije in večji obseg njegove podpore udeležencem.

\section{LITERATURA}

Bates, A. W. T. (1997). Technology, open learning and distance education. London and New York: Routledge.

Bates, T., in Poole, G. (2003). Effective teaching with technology in higher education. Foundations for success. San Francisco: Jossey-Bass.

Bregar, L., Zagmajster, M., in Radovan, M. (2010). Osnove e-izobraževanja. Andragoški center Slovenije: Ljubljana. 
Downes, S. (2005). »E-learning 2.0«. ELearn magazine. http://elearnmag.org/subpage.cfm?section=ar ticles\&article=29-1 (pridobljeno 16. 6. 2006).

Ehlers, U-D. (2009). New e-learning cultures for adult learning. Lifelong Learning in Europe, 14 (3): 134-141.

Horton, W. (2006). E-learning by design. San Francisco: Pfeiffer.

JISC (2009). Effective Practice in a Digital Age. A Guide to Technology-enhanced Learning and Teaching. HEFCE. http://www.jisc.ac.uk/practice (pridobljeno 12. 12. 2009).

Jolliffe, A., Ritter, J., in Stevens, D. (2001). The online learning handbook: developing and using web-based learning. London and Sterling: Kogan Page.

Prensky, M. (2007). The digital games-based learning revolution. New York: Paragon House.

Siemens, G. (2004). Categories of eLearning. Elearnspace. http://www.elearnspace.org/Articles/ elearningcategories.htm (pridobljeno 16. 6. 2006).

Siemens, G. (2007). »Connectivism: A learning theory for the digital age «. Elearnspace. Everything E-learning. http://www.elearnspace.org/Articles/ connectivism.htm (pridobljeno 14. 11. 2007).

Siemens, G., in Tittenberger, P. (2009). Handbook of emerging technologies for learning. http://umanitoba.ca/learning_technologies/cetl/HETL.pdf (pridobljeno 28. 11. 2009). 